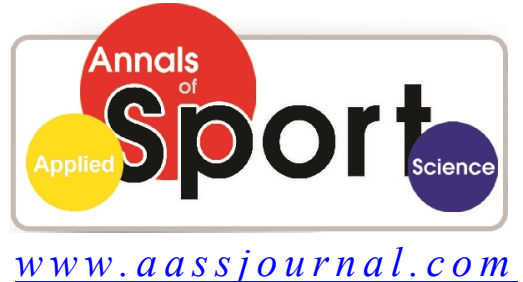

ISSN (Online): $2322-4479$

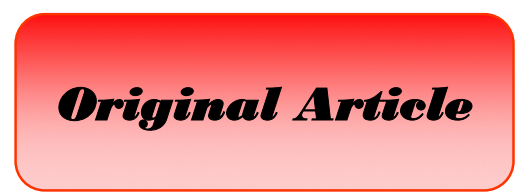

Received: 07/12/2013

Accepted: 29/03/2013

\title{
Liver ABCA1 Gene Expression in Male Rats: Effects of High-intensity Treadmill Running and Black Crataegus-pentaegyna (Siayh-Valik) Extraction
}

\section{${ }^{1}$ Abbass Ghanbari-Niaki* ${ }^{1}$ Monireh Gholizadeh, ${ }^{1}$ Safieyh Ghanbari-Abarghooi, ${ }^{2}$ Fatemeh Roudbari, ${ }^{3}$ Mohammad Javad Chaichi}

1. Exercise Biochemistry Division, Faculty of Physical Education and Sport Science, University of Mazandaran, Baboulsar, Iran.

2. Department of Molecular and Cell Biology, Faculty of Basic Sciences, University of Mazandaran, Baboulsar, Iran.

3. Analytical Chemistry, Faculty of Chemistry, University of Mazandaran, Baboulsar, Iran.

\begin{abstract}
The purpose of the current study was to investigate the effect of a high- intensity treadmill running ( 8 weeks) with or without aqueous extraction of black Crataegus-Pentaegyna (Siyah -Valik) on liver ABCA1 mRNA expression and plasma HDL-C, total, and direct bilirubin concentration in male rats. Twenty Wistar male rats (4-6 weeks old, 140-170 g weight) were used. Animals were randomly assigned into training $(\mathrm{n}=10)$ and control $(\mathrm{n}=10)$ groups and further divided into saline-control $(\mathrm{SC}, \mathrm{n}=5)$, salinetraining (ST, $n=5)$, black Crataegus-Pentaegyna (Siyah-Valik) Control (SVC, $n=5)$, and black CrataegusPentaegyna (Siyah-Valik)-training (SVT, $n=5)$ groups. Training groups have performed a high-intensity running program $(34 \mathrm{~m} / \mathrm{min}$ on $0 \%$ grade, $60 \mathrm{~min} /$ day and 5 days/week) on a motor-driven treadmill for 8 weeks. Animals were orally fed with black Crataegus-Pentaegyna (Siyah -Valik) extraction ( $500 \mathrm{mg} / \mathrm{kg}$ body weight) and saline solution for last six weeks. A significant differences have found in liver ABCA1 gene expression between SVC and SVT $(\mathrm{P}<0.003)$ and between $\mathrm{SVC}$ with $\mathrm{SC}$ groups $(\mathrm{P}<0.038)$. HDL-C levels were significantly $(\mathrm{P}<0.036)$ between groups. A higher HDL level was found in SV treated groups and between SVC and SC groups. The levels of bilirubin total and bilirubin direct remained unchanged. The current results show that high-intensity treadmill running affected liver ABCA1 mRNA expression in different directions in saline (increase) and SV (decrease) treated animals. Findings also indicate an opposite pattern of change in saline and SV treated animals at rest. It seems the existence of opposite effect of exercise with supplementation of SV might be attributed to the suppression of lignds which is provided by SV supplementation at rest. This in turn might be also taking in account in lower liver ABCA1 mRNA expression and its related nuclear receptors such as LXR in SVT not ST groups.
\end{abstract}

Key Words: ATP-binding cassette protein-A1 (ABCA1), HDL-C, Male Rats, High-intensity running, Black Crataegus-Pentaegyna (Siyah -Valik).

Corresponding Author:

Abbass Ghanbari-Niaki

E-mail: ghanbara@umz.ac.ir 


\section{INTRODUCTION}

Liver has well been recognized as a main organ in blood glucose regulation, and lipid and lipoprotein metabolism, short energy storage by deposition of excess blood glucose in to glycogen, bile acid secretion, nitrogen fixation, ketogenesis, toxification, and HDL biogenesis (1-5). Regarding HDL biogenesis and its plasmatic formation, liver is accounted as a chief organ for a lipid-poor or lipid-free Apo lipoprotein type A (Apo-I) secretion into blood into blood circulation (6). The exercise has been shown to increase genes which are involved in HDL-C biogenesis and its plasmatic formation such as ABCA1 and ABCG1 genes. The responses of ATP-binding cassette protein transporters (ABCs) family member to different types of physical exercise in human and animal has also been investigated by several researchers (7-10). ATP-binding cassette protein transporters A, particularly, ABCA1 is a multispan molecule with high expression level in the heart and other tissues and upregulated by several factors such as cholesterol influx and physical activity (11). On the other hand, the role of various medicinal plants in reducing heart disease is well established. Crataegus (Valik) species is well known in phytotherapy for the treatment of many cardiovascular diseases (12). Carategus Pentaegyna (Sorkh valik) is the one of best known and favorite edible wild fruit of the Crataegus species, (Rosaceae) which is exist in Mazandaran and other Northern states of Iran. This fruit is believed to have some medicinal beneficial effect on cardiovascular function, blood pressure, and lipid metabolism. In Mazandaran province, this fruit is consumed freshly and as jam, vinegar, and sauce (13). In despite, some information about the effects of Crataegus species extraction (14). There is very less information about the effect of the black Crataegus Pentaegyna (Siyah-Valik) extraction on ABCA1 mRNA expression with or without a high-intensity treadmill running program. This study was conducted to evaluate of the liver ABCA1 mRNA expression eresponse. The second purpose to see a possible change in ABCA1 could be accompanied with significant changes in plasma HDL, bilirubin total and direct concentrations to a high- intensity treadmill running programm and black crataegus pentaegyna (Siyah-Valik) in male rat.

\section{MATERIALS AND METHODS}

Animals. All experiments involving animals were conducted according to the policy of Iranian convention for the protection of vertebrate animals used for experimental and other scientific purposes; the protocol was approved by the Ethics Committee of the Sciences, University of Mazandaran (UMZ) and Babol University of Medical Sciences (BUMS, Mazandaran, Iran). Twenty Wistar male rats (4-6 weeks old, 140-170 gr weight) were acquired from the Pasteur's Institute (Amol, Mazandaran), and maintained in the Central Animal House of the Faculty of Physical Education and Sports Science of UMZ. Five rats were housed per cage (46-L) with a 12-hour: 12hour light-dark cycle Temperature and humidity were maintained at $22^{\circ} \mathrm{C} \pm 1.4^{\circ} \mathrm{C}$ and $50 \% \pm 5 \%$, respectively. Diets (a pellet form) and water were provided ad libitum. Animals were randomly assigned into control $(n=10)$ and training $(n=10)$ groups. Rats were further divided into saline-control $(\mathrm{SC}, \mathrm{n}=5)$, saline-training $(\mathrm{ST}, \mathrm{n}=5)$, Black Crataegus - Pentaegyna (Siyah - Valik)control, Valik - control (SVC, n =5), and Sorkh Valik - training (SVT) $(n=5)$. The control groups remained sedentary; whereas the training groups underwent a high 
intensity $(35 \mathrm{~m} / \mathrm{min})$ treadmill running program.

Plant Material. The ripped fruit and well washed samples of red Crataegus Pentaegyna (Sorkh - Valik) were collected from the Neka forest in the Mazandaran province of Iran. Fruits were dried in oven at $35^{\circ} \mathrm{C}$ for 4 days and fine powdered by using a. Plant Material was identified by herbarium collection in Department of Biology, Faculty of Basic Sciences, University of Mazandaran (UMZ) Baboulsar, and Mazandaran, Iran.

Preparation of the Crataegus extraction. The whole ripped and dried fruits of Crataegus-Pentaegyna were grounded in house electronic grinder to a fine powder. The extract was prepared according to the Cai et al (15). Rats were orally received a single dose $(500 \mathrm{mg} / \mathrm{kg}$ of body weight or 10 $\mathrm{ml} / \mathrm{kg}$ of body weight) of liquid extraction of Siyah-Valik at the end of daily exercise training session (16). The saline groups were treated with the same volume of saline solution.

Liver Biopsy and plasma HDL-C, Total and Direct Bilirubin Concentrations. Seventy-two hours after the last training session, rats were anesthetized with intra peritoneal administration of a mixture of ketamine (30-50mg / kg body weight) and xylazine (3- $5 \mathrm{mg} / \mathrm{kg}$ body weight). The liver was excised, cleaned, divided into two pieces, washed in ice cold saline, and immediately frozen in liquid nitrogen and stored at $-80^{\circ} \mathrm{C}$ until RNA extraction. Blood was also collected in test tubes contain EDAT $(1 \mathrm{mg} / \mathrm{mL})$ as anticoagulant, and immediately processed for plasma preparation, during a 15 min centrifugation at $3000 \mathrm{rpm}$. Plasma was stored at $-80 \mathrm{C}$ too, for future analysis. Plasma High Density Lipoprotein (HDL) was determined by enzymatic colorimetric method (Pars Azmoun, Tehran, Iran); Plasma total bilirubin (BileT) was determined by enzymatic colorimetric method (Pars Azmoun, Tehran, Iran); intra-assay coefficient of variation and sensitivity of the method were $3.05 \%$ and $0.03 \mathrm{mg} / \mathrm{dL}$, respectively. Plasma Direct bilirubin (BileD) was determined by enzymatic colorimetric method (Pars Azmoun, Tehran, Iran); intraassay coefficient of variation and sensitivity of the method were $3.12 \%$ and $0.01 \mathrm{mg} / \mathrm{dL}$, respectively.

RNA, cDNA Synthesis and Real-time PCR. Total RNA was extracted from $30 \mathrm{mg}$ of liver tissue using RNA purification kits (QIAGEN, Cat.No: 71104). Complementary DNA (cDNA) was extended by using cDNA synthesis kit (QuantiTect Reverse Transcription Kit cDNA synthesis (Qiagen), Cat.No: 205310) according to the manufacturer's instructions. Real-time quantitative PCR was performed using Quanti Fast SYBR Green PCR Kit (Cat. No. 204052; Qiagen, GmbH, Germany) in using $10 \mu$ reaction containing $1 \mu$ single-strand cDNA, $5 \mu$ l Master Mix, $1 \mu \mathrm{l}$ of the each forward and reverse primers and $2 \mu \mathrm{l}$ Transferee water. Expected fragment size and Oligonucleotide primer sequences for ABCA1, and GAPDH genes are F: 5'-ACGAGATTGATGACCGCCTC, R: 5'-GCATCCACCCCACTCTCTTC, and F: 5'-GTGCCAGCCTCGTCTCATAG, R: 5'-GACTGTGCCGTTGAACTTGC, Respectively. The PCR was carried out on BIO RAD (C1000 TM Thermal Cycler). Real time PCR system is listed in Table 1. Product specificity was confirmed in the initial experiments by $1.5 \%$ agarose gel electrophoresis and routinely by melting curve analysis.

Statistical Analysis. The relative levels of mRNA were analyzed by using a comparative threshold cycle method (15). Data were normalized and normal distribution was found. A two way ANOVA 
were employed and significance was accepted at $\mathrm{P}=0.05$. All findings were expressed as means \pm SE and SPSS (Version
13; SPSS, Chicago, IL) software was used for data analysis.

Table 1. Real-time Cycler Conditions

\begin{tabular}{ccc}
\hline Steps & Time & Temperature \\
\hline PCR initial activation step & $5 \mathrm{~min}$ & $95^{\circ \mathrm{C}}$ \\
\hline Two-step cycling & & \\
\hline Denaturation & $10 \mathrm{~s}$ & $95^{\circ \mathrm{C}}$ \\
\hline 45 Cycle Combined annealing/extension & $30 \mathrm{~s}$ & $95^{\circ \mathrm{C}}$ \\
\hline Melting Curve & $6.5 \mathrm{~min}$ & 55 to $95^{\circ \mathrm{C}}$ \\
\hline
\end{tabular}

\section{RESULTS}

ABCA1 mRNA Expression. A significant differences was found in liver ABCA1 gene expression between $\mathrm{SVC}$ and SVT $(\mathrm{P}<0.003)$ and between SVC with SC groups $(\mathrm{P}<0.038)$ (Fig. 1).

Plasma Biochemical Variables. Data analysis revealed a significant differences between groups $(\mathrm{F}=2.905, \mathrm{P}<0.03)$. Using a suitable following post hoc test showed that plasma HDL-C levels were significantly $(\mathrm{P}<0.036)$ higher in $\mathrm{SV}$ treated rats when compared with $\mathrm{S}$ groups. However, a significant difference also was found between SVC and SC groups (Fig 2). The levels of bilirubin total and bilirubin direct remained unchanged (Table 2).

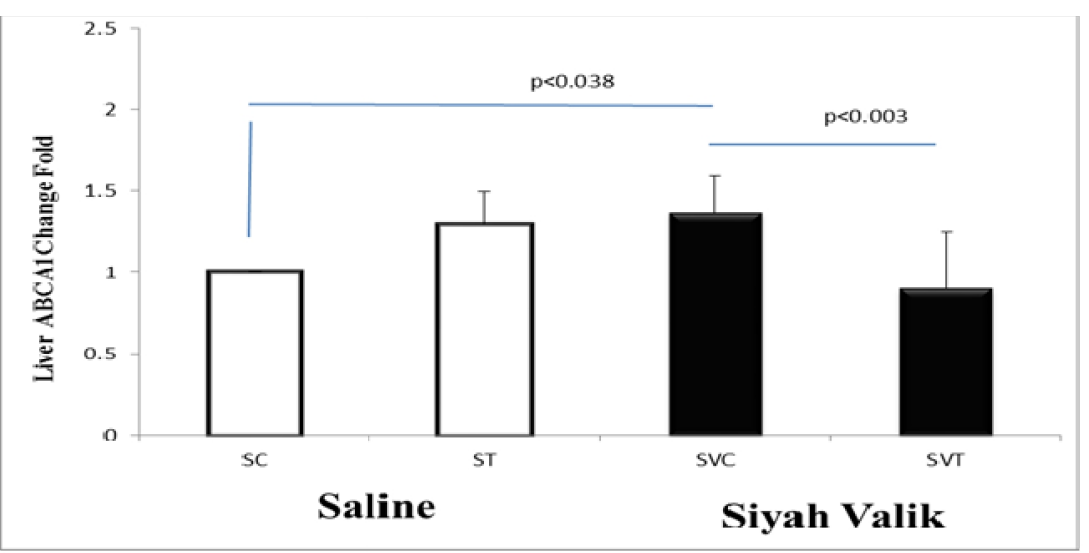

Figure1. Real-Time PCR of Liver ABCA1 Relative mRNA Expression in Wild-Type Male Rats. The results are expressed as mean \pm SD. Each column is for five rats per group. SC: Saline-Control, ST: Saline- Training, SVC: Crataegus-Pentaegyna-Control (Siyah Valik), and SVT: CrataegusPentaegyna-Training (Siyah Valik).

Table 2. Comparative changes Plasma Variables Concentration (mg/dL)

\begin{tabular}{lcccccc}
\hline \multicolumn{1}{c}{ Variables } & SC & ST & SVC & SVT & p \\
\hline BileT, mg/dl & $0.68 \pm 0.037$ & $0.72 \pm 0.03$ & $0.76 \pm 0.024$ & $0.78 \pm 0.02$ & 0.371 \\
\hline BileD mg/dL & $0.18 \pm 0.0$ & $0.14 \pm 0.024$ & $0.18 \pm 0.02$ & $0.18 \pm 0.02$ & 0.061 \\
\hline The results are expressed as mean \pm SD. & Each column is for five rats per \\
group. SC: Saline-Control, ST: Saline- Training, SVC: Crataegus- \\
Pentaegyna-Control (Siyah Valik), and SVT: Crataegus-Pentaegyna- \\
Training (Siyah Valik).
\end{tabular}

Ghanbari-Niaki, A., and et al. (2014). Ann Appl Sport Sci, 2(1): 37-44. 


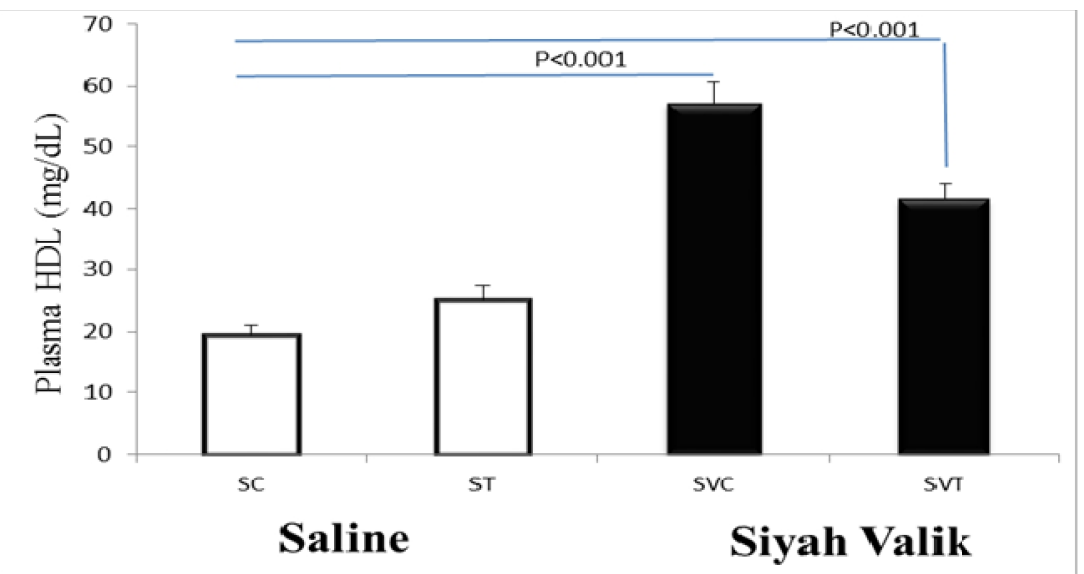

Figure 2. Plasma HDL Concentrations (mg/dL) in Wild-Type Male Rats. The results are expressed as mean $\pm \mathrm{SD}$. Each column is for five rats per group. SC: Saline-Control, ST: Saline- Training, SVC: CrataegusPentaegyna-Control (Siyah Valik), and SVT: Crataegus-Pentaegyna-Training (Siyah Valik).

\section{DISCUSSION}

The results of the present study indicate that SV extraction was able to enhance liver ABCA1mRNA expression in our experimental condition. The other main findings of the current study were a higher ABCA1 mRNA expression in SV treated groups. The results also indicated that highintensity treadmill running program with or without SV treatment had different impact on liver ABCA1mRNA expression. Another main finding was a higher plasma HDL-C in SVC group when compared with SC, ST, and SVT groups. It should be noted that on the basis of our Knowledge, this is the first report to demonstrate alterations of male rat liver ABCA1mRNA expression in response to a high intensity training and black Crataegus - Pentaegyna (Siyah - Valik) extraction. It is well known that ABCA1 is the initiator element of reverse cholesterol transport (RCT) process which plays a crucial role in HDL biogenesis, maturation, and its plasmatic formation. The effect of moderate intensity of treadmill running with moderate and long term $(60,90 \mathrm{~min})$ for 6 and 12 weeks on ABCA1mRNA expression in rat liver, small intestine, and heart tissues have been previously reported by several investigators $(8-10,16)$. Our finding related to ABCA1mRNA expression in saline treated animals is in agreement with previous reports, but the results of $\mathrm{SV}$ trained rats is not in consistent with other reports. However, according to GhanbariNiaki et al. (2013) using the same treadmill running protocol resulted in a similar pattern but not significant changes in rat heart ABCA1mRNA expression (8). It seems that the tendency of treadmill-running induced reduction in ABCA1mRNA expression is similar in both liver and heart tissues following the same amount of SV extraction. A higher level of ABCA1mRNA expression in liver with $\mathrm{SV}$ treatment at rest and a reduction following the treadmill running was a novel and interested finding. The antilipidemic, antioxidative, and lowering cholesterol effects of Crataegus species very well known $(11,12)$, but the information about the effect of black CrataegusPentaegyna (Siyah-valik) on ABCA1 mRNA at rest and training is lacking. It has been suggested that the activation of PPAR- $\gamma$ 
ligand is resulted in a Primary activation of LXR which is in turn up-regulates the expression of transporter ABCG1 and ABCA1 and following these an increase in reverse cholesterol transport process. Would be expected as the present results showed, SV treatment resulted in a higher expression of ABCA1 in SV-treated rats, while a lower BCA1mRNA expression was observed at the end of treadmill running program in trained liver with SV treatment $(17,18)$. It is not clear that by which mechanism(s) black Crataegus - pentaegyna (Siyah - Valik) could affect ABCA1mRNA, particularly at resting not training stats. However, the effect of SV treatment on ABCA1mRNA expression at rest might be due to the nature and contents of SV. The analyze of SV whole dried fruit has shown to have high levels of polyunsaturated fatty acid (PUFA) contents with the best PUFA/ (saturated fatty acids) SFA ratio, and also the high levels of phenolics components (15). On the basis of Our GC-MS data findings, the main compositions of the Crataegus-Pentaegyna (SV) sample were oleic acid (13.44\%), palmitic acid (7.72\%), linoleic acid $(22.43 \%)$ and arashidonic acid $(0.47 \%)$. On the other hand, it has been suggested that the liver $\mathrm{X}$ receptors (LXRs) as nuclear receptors are activated by endogenous oxysterols, oxidized derivatives of cholesterol (19). Thus it might be that the conversion of cholesterol to the oxysterol ligands for LXRs has drived the expression of ABCA1 SV treated liver. It has also shown that, unsaturated fatty acids were might also suppress the expression of ABCA1 and ABCG1 transcription by antagonizing the effects of sterols on LXR activation (20). With consider to the present results, it might be stated that these change possibly increased the adjustment of the ABCA1 gene to justify through other signaling pathways, including activation of peroxisome proliferation activated receptors (PPARs) by fatty acids and flavonoid compounds found in hawthorn (as natural ligands of PPAR activators) $(21,22)$. Thus, a higher HDL levels in SV treated rats could be attributed to high level expression of ABCA1 in SV treated liver treated with SV solution.

\section{CONCLUSION}

Taken together, the findings of the current study indicate that SV extraction enhanced plasma HDL levels, but the effect of $\mathrm{SV}$ at rest reduced by high intensity treadmill running in somewhat. Data also indicate that $\mathrm{SV}$ extraction induced an exercise-like effect on ABCA1mRNA expression at rest, while it showed opposite response to high intensity treadmill running program. The present study has shown that SV extraction could be consider as cardioprotector herb such as Crataegus oxyacantha for minimizing atherosclerotic process. Further studies are warranted to clarify the effects of different parts of this Crataegus species on other related genes which are involved in ABCA1mRNA expression.

\section{ACKNOWLEDGEMENTS}

We wish to thank Dr. A. Naghi Nejad (Department of Biology, University of Mazandaran, Iran) and N. Zare- Kookandeh; Master of Sports Physiology for helpful comments and guidance.

\section{REFFRENCES}

1. Fuchs C, Claudel T, Trauner M. Bile acid-mediated control of liver triglycerides. Seminars in liver disease. 2013;33(4):330-42. Epub 2013/11/14.

2. Kashiwagura T, Deutsch CJ, Taylor J, Erecińska M, Wilson DF. Dependence of gluconeogenesis, urea synthesis, and energy metabolism of hepatocytes on intracellular pH. Journal of Biological Chemistry. 1984;259(1):237-43.

3. Koliaki C, Roden M. Hepatic energy metabolism in human diabetes mellitus, obesity and non-alcoholic fatty liver disease. Molecular and cellular endocrinology. 2013;379(1-2):35-42. Epub 2013/06/19. 
4. Mashek DG. Hepatic Fatty Acid Trafficking: Multiple Forks in the Road. Advances in Nutrition: An International Review Journal. 2013;4(6):697-710.

5. Reddy JK, Rao MS. Lipid metabolism and liver inflammation. II. Fatty liver disease and fatty acid oxidation. American journal of physiology Gastrointestinal and liver physiology. 2006;290(5):G852-8. Epub 2006/04/11.

6. Chisholm JW, Burleson ER, Shelness GS, Parks JS. ApoA-I secretion from HepG2 cells: evidence for the secretion of both lipid-poor apoA-I and intracellularly assembled nascent HDL. Journal of lipid research. 2002;43(1):36-44. Epub 2002/01/17.

7. Ghanbari-Niaki A. Treadmill exercise training enhances ATP-binding cassette protein-A1 (ABCA1) expression in male rats' heart and gastrocnemius muscles. Int J Endocrinol Metab. 2010;8(4):206-10.

8. Ghanbari-Niaki A, Ghanbari-Abarghooi S, Rahbarizadeh F, Zare-Kookandeh N, Gholizadeh M, Roudbari F, et al. Heart ABCA1 and PPAR- $\alpha$ Genes Expression Responses in Male rats: Effects of High Intensity Treadmill Running Training and Aqueous Extraction of Black Crataegus-Pentaegyna. Res Cardiovasc Med. 2013;1(5):1539.

9. Ghanbari-Niaki A, Khabazian BM, Hossaini-Kakhak SA, Rahbarizadeh F, Hedayati M. Treadmill exercise enhances ABCA1 expression in rat liver. Biochemical and biophysical research communications. 2007;361(4):841-6. Epub 2007/08/11.

10. Khabazian BM, Niaki AG, Rahbarizadeh F, Kakhak AH, Noghabi MJ. The Effect of 6 Weeks of Endurance Training on the Expression of Hepatic ABCA1 in Male Wistar Rats. World Journal of Sport Sciences. 2008;1(1):01-7.

11. Chen JD, Wu YZ, Tao ZL, Chen ZM, Liu XP. Hawthorn (shan zha) drink and its lowering effect on blood lipid levels in humans and rats. World review of nutrition and dietetics. 1995;77:147-54. Epub 1995/01/01.

12. Akila M, Devaraj H. Synergistic effect of tincture of Crataegus and Mangifera indica L. extract on hyperlipidemic and antioxidant status in atherogenic rats. Vascular pharmacology. 2008;49(4-6):173-7. Epub 2008/08/30.

13. Ebrahimzadeh MA, Bahramian F. Antioxidant activity of Crataegus pentaegyna subsp. elburensis fruits extracts used in traditional medicine in Iran. Pakistan journal of biological sciences: PJBS. 2009;12(5):413-9. Epub 2009/07/08.

14. Barros L, Carvalho AM, Ferreira IC. Comparing the composition and bioactivity of Crataegus Monogyna flowers and fruits used in folk medicine. Phytochemical analysis : PCA. 2011;22(2):181-8. Epub 2010/09/18.

15. Livak KJ, Schmittgen TD. Analysis of relative gene expression data using real-time quantitative PCR and the 2(Delta Delta C(T)) Method. Methods (San Diego, Calif). 2001;25(4):402-8. Epub 2002/02/16.

16. Ghanbari-Niaki A, Saghebjoo M, Hedayati M. A single session of circuit-resistance exercise effects on human peripheral blood lymphocyte ABCA1 expression and plasma HDL-C level. Regulatory peptides. 2011;166(13):42-7. Epub 2010/08/24.

17. Li AC, Binder CJ, Gutierrez A, Brown KK, Plotkin CR, Pattison JW, et al. Differential inhibition of macrophage foam-cell formation and atherosclerosis in mice by PPARalpha, beta/delta, and gamma. The Journal of clinical investigation. 2004;114(11):1564-76. Epub 2004/12/04.

18. Yoshikawa T, Ide T, Shimano H, Yahagi N, Amemiya-Kudo M, Matsuzaka T, et al. Cross-talk between peroxisome proliferator-activated receptor (PPAR) alpha and liver X receptor (LXR) in nutritional regulation of fatty acid metabolism. I. PPARs suppress sterol regulatory element binding protein-1c promoter through inhibition of LXR signaling. Molecular endocrinology (Baltimore, Md). 2003;17(7):1240-54. Epub 2003/05/06.

19. Zhao C, Dahlman-Wright K. Liver X receptor in cholesterol metabolism. The Journal of endocrinology. 2010;204(3):233-40. Epub 2009/10/20.

20. Oram JF, Heinecke JW. ATP-binding cassette transporter A1: a cell cholesterol exporter that protects against cardiovascular disease. Physiological reviews. 2005;85(4):1343-72. Epub 2005/09/27.

21. Peluso MR. Flavonoids attenuate cardiovascular disease, inhibit phosphodiesterase, and modulate lipid homeostasis in adipose tissue and liver. Experimental biology and medicine (Maywood, NJ). 2006;231(8):128799. Epub 2006/09/02.

22. Yu YE. The effects of antioxidants kaempferol and ascorbic acid on liver X receptor alpha (LXR-a) in TNF-a stimulated human hepatocarcinoma HEPG2 cells: Universiti Tunku Abdul Rahman (UTAR); 2011. 
تازههاى علوم كاربردى ورزش

مقاله اصيل

دوره دوم، شماره اول

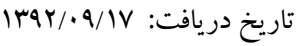

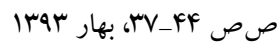

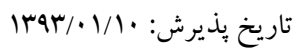

\section{ياسخ زن ABCA1 كبدى در رتهاي نر: اثر تمرين شديد و عصاره خام كراتاكوس (سياه وليك)}

'عباس قنبرى نياكى *' 'منيره قلىزاده، 'صفيه قنبرى ابرقويى، 'فاطمه رودبارى، "محمدجواد جايجيى

ا. كَروه بيوشيمى ورزشى، دانشكده تربيتبدنى و علوم ورزشى، دانشكاه مازندران، بابلسر، ايران.

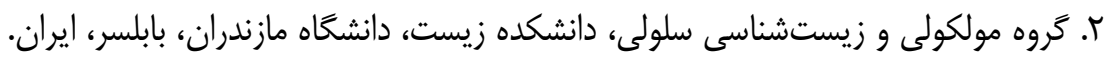

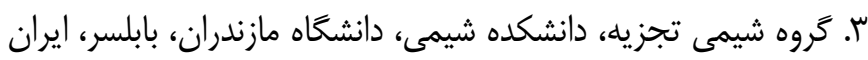

جكيده

فعاليتهاى ورزشى منظه و بجرهمندى از داروهاى كياهى بر سوخت و ساز مناسب جربى و تنظيمه آن در كبد اثر دارد. از آنجايى كه اين تأثير احتمالاً

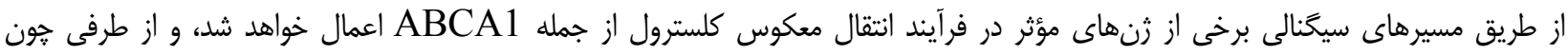

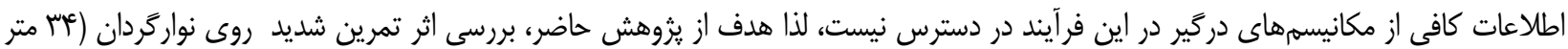

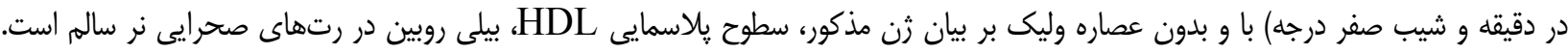

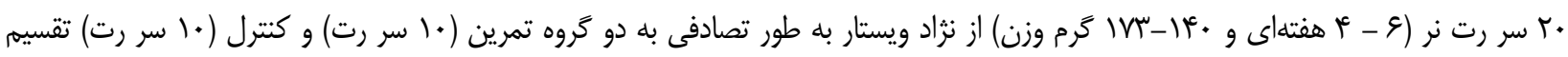

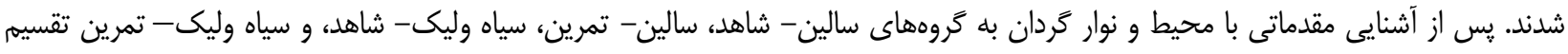

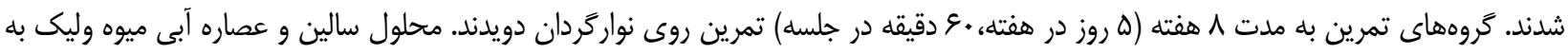

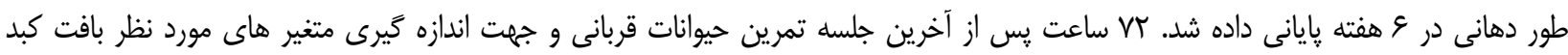

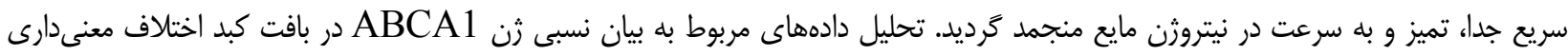

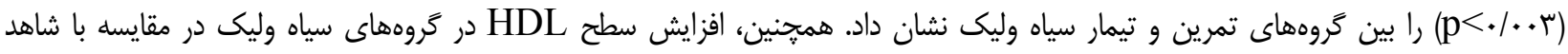

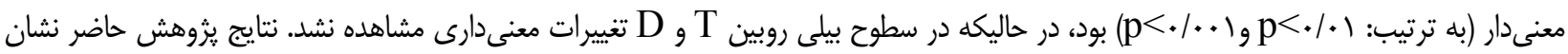

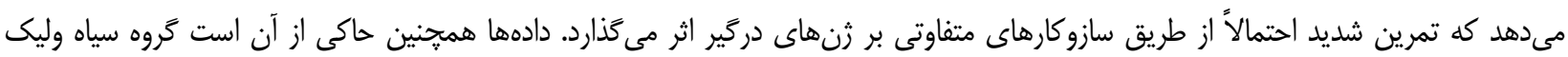

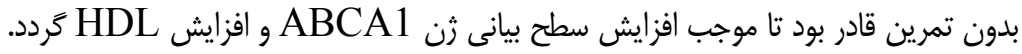
وازَّان كليدى: ABCA1، HDL، بيلى روبين، تمرين ورزشى شديد و عصاره وليك.

عباس قنبرى نياكى ghanbara@umz.ac.ir بست الكترونيك نيرى 